\title{
63. Release of a Fy Active Sialoglycopeptide from Human Erythrocytes by Crystalline Chymotrypsin Treatment
}

\author{
By Seiichi Ohкuma, ${ }^{*)}$ Shigenori Ikemoto, ${ }^{* *)}$ Chitose Mryauchi, ${ }^{*}$ \\ and Tanemoto FuruhatA, M.J.A.***) \\ National Research Institute of Police Science, Tokyo
}

(Comm. March 12, 1966)

Many investigators ${ }^{1)-3)}$ reported that the $\mathrm{M}, \mathrm{M}^{\mathrm{x}}, \mathrm{N}, \mathrm{S}, \mathrm{Fy}^{\mathrm{a}}$, $\mathrm{Lu}^{\mathrm{a}}$, Yta $\mathrm{Y}^{\mathrm{a}}$, and I blood-group agglutinogens on human erythrocytes were destroyed by some proteinases, trypsin, chymotrypsin, papain, bromelin, and ficin. Recently, Morton ${ }^{4}$ showed that crystallized chymotrypsin destroyed the agglutinogens $\mathrm{S}, \mathrm{Fy}^{\mathrm{a}}, \mathrm{Yt}^{\mathrm{a}}$, and possibly $\mathrm{K}$ and $\mathrm{Lu}^{\mathrm{a}}$.

This paper describes liberation of a $\mathrm{Fy}^{\mathrm{a}}$ active sialoglycopeptide from human erythrocytes by treatment with crystalline chymotrypsin in a low concentration.

Experimental methods. Hemagglutination tests of human erythrocytes before and after chymotrypsin treatment. The tests were carried out by using anti-A, B, H(O), Le $\mathrm{e}^{\mathrm{a}}, \mathrm{M}, \mathrm{N}, \mathrm{S}, \mathrm{s}, \mathrm{Jk}^{\mathrm{a}}, \mathrm{Jk}^{\mathrm{b}}$, $\mathrm{K}, \mathrm{k}, \mathrm{Fy}^{\mathrm{a}}, \mathrm{I}, \mathrm{P}, \mathrm{Q}, \mathrm{C}\left(\mathrm{rh}^{\prime}\right), \mathrm{D}\left(\mathrm{Rh}_{0}\right), \mathrm{E}\left(\mathrm{rh}^{\prime \prime}\right), \mathrm{c}\left(\mathrm{hr}^{\prime}\right), \mathrm{e}\left(\mathrm{hr}^{\prime \prime}\right), \mathrm{Hg}, \mathrm{Wr}^{\mathrm{a}}$, $\mathrm{Wb}, \mathrm{Sr}^{\mathrm{a}}$, and $\mathrm{Kp}$ sera. Absorption test of sialoglycopeptide isolated. Absorption test of sialoglycopeptide liberated from human erythrocytes by chymotrypsin treatment, was carried out as follows: Seven $\mathrm{mg}$ of sialoglycopeptide was dissolved in $0.5 \mathrm{ml}$ of saline. The solution was diluted with saline by doubling dilution technique. To $0.05 \mathrm{ml}$ of each diluted solution was added $0.05 \mathrm{ml}$ of anti-Fy $\mathrm{y}^{\mathrm{a}}$ serum (agglutination titer 8, Knickerbocker Biological Inc., U.S.A.). After continuous incubation at $37^{\circ} \mathrm{C}$ for 4 hours, at $15^{\circ} \mathrm{C}$ for 2 hours, and at $5^{\circ} \mathrm{C}$ for 15 hours, $0.05 \mathrm{ml}$ of $2 \%$ red blood cells $\left(\mathrm{Fy}^{\mathrm{a}}\right.$ positive cells) suspension was added to the incubation mixture, and the mixture was allowed to stand at $37^{\circ} \mathrm{C}$ for 1 hour and washed three times with saline which was previously warmed at $30^{\circ} \mathrm{C}$. To the mixture was added 2 drops of Coombs serum. The mixture was thoroughly mixed, placed at $37^{\circ} \mathrm{C}$ for 30 minutes, centrifuged at 1,000 r.p.m. for 2 minutes, and examined. Paper electrophoresis. A Whatman No. 3 MM paper strip (32 cm width $\times 46 \mathrm{~cm}$ length) was moistened with pyridine-acetic acid-acetone-water (10:0.4:20:70, by volume)

*) Laboratory of Biochemistry.

**) Laboratory of Serology.

***) Director of the Institute. 
buffer and pressed between two sheets of filter paper. The paper strip was placed in an electrophoretic apparatus and sample solutions (each solution contained about $0.5 \mathrm{mg}$ of sample) were applied at the starting line. Electrophoresis was carried out by the horizontal open strip method at $300 \mathrm{~V}$ for 6 hours. Platinum electrodes were used. After electrophoresis, the paper strip was dried at room temperature. The dry paper strip was divided lengthwise into 4 ribbons which were separately stained with methylene blue, periodate-Schiff, amidoblack-10 B, and ninhydrin reagents, or the guide strip of the dry paper strip was stained with the methylene blue. Staining. 1. Methylene blue. The technique described in a previous paper ${ }^{5)}$ was used. 2. Periodate-Schiff (PAS). The technique described by McGuckin and McKenzie ${ }^{6}$ was used. 3. Amidoblack-10 B. The technique of Grassmann and Hannig ${ }^{7)}$ was applied. 4. Ninhydrin. The technique of Montgomery and $\mathrm{Wu}^{8)}$ was used.

Results. Human bloods from 12 donors were separately subjected to the following enzymatic treatment and chemical procedure. Before and after incubation with crystallized chymotrypsin, the agglutinability of erythrocytes was qualitatively tested with various anti-blood-group sera. One volume of washed packed red blood cells (the red blood cells from a donor were washed 12 times with saline) was mixed with 3 volumes of phosphate buffered-saline*) of $\mathrm{pH} 7.7$ which was previously warmed at $37^{\circ} \mathrm{C}$. To the mixture was added 0.1 volume of $3 \mathrm{mg} / \mathrm{ml}$ solution of crystallized trypsin (Sigma or Eisai Co. preparation) in phosphate buffered-saline. The chymotrypsin solution was prepared before use. The final concentration of chymotrypsin in the incubation mixture, was $0.0732 \mathrm{mg} / \mathrm{ml}$. After incubation with adequate shaking at $37^{\circ} \mathrm{C}$ for 1 hour, the mixture was cooled in ice water and centrifuged. The supernatant solution was deprotenized with 50\% trichloroacetic acid solution and filtered through Whatman No. 3 MM paper. The filtrate was shaken 3 times with ethyl ether to remove trichloroacetic acid. The clear colorless aqueous solution was neutralized to $\mathrm{pH} 6.0$ with $2 \mathrm{~N}$ sodium hydroxide and dialyzed for 24 hours through a cellophan tube of Visking Co. against 20 volumes of water at $3-4^{\circ} \mathrm{C}$. The dialyses were repeated 4 times. The dialyzed solution was concentrated to near dryness at $30^{\circ} \mathrm{C}$ in a rotary evaporator and dried over phosphorous pentoxide in a vacuum desiccator. The dry residues obtained from bloods (total 2.4 litre) of 12 donors were mixed and taken up in $3 \mathrm{ml}$ of water and centrifuged to remove insoluble matter. The supernatant was evaporated over

*) Fourteen point two $\mathrm{g}$ of $\mathrm{Na}_{2} \mathrm{HPO}_{4}$ and $80.0 \mathrm{~g}$ of $\mathrm{NaCl}$ were dissolved in 1 litre of water. One volume of the solution was mixed with 9 volumes of water and the mixture solution was adjusted to $\mathrm{pH} 7.7$ with $\mathrm{N}, \mathrm{NaOH}$, 
phosphorous pentoxide in a vacuum desiccator. The dry residue which would henceforth be refered to as the crude preparation, weighed $106 \mathrm{mg}$. The crude preparation was dissolved in $1.0 \mathrm{ml}$ of water. The solution was subjected to paper electrophoresis to examined its components and 4 ribbons obtained were separately stained with the 4 reagents described above. Electropherograms are shown in Fig. 1. As seen from the figures, the crude

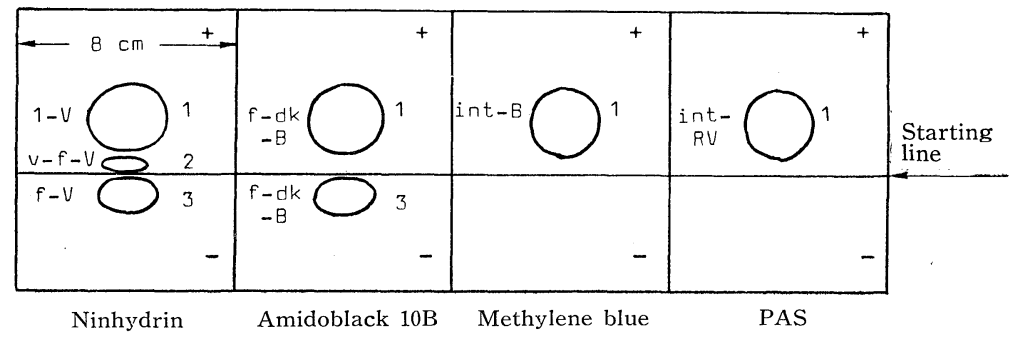

Fig. 1. Paper electropherogram of the crude preparation.

$\mathrm{dk}$ : dark f: faint $\mathrm{l}$ : light int: intense $\mathrm{v}$ : very B: Blue R: Red V: Violet

preparation was separated into 3 components, i.e., the spots 1 , 2 , and 3. The spots 1 and 2 migrated toward the anode and the spot 3 migrated toward the cathode. The spot 1 gave a blue color with the methylene blue ${ }^{9)}$ suggesting the presence of sialomucopeptide or sialomucoprotein and showed a purple color with the $\mathrm{PAS}^{6)}$ indicating the presence of carbohydrate material associated with protein or peptide, but slightly reacted with the amidoblack-10 $\mathrm{B}^{\text {7) }}$ and ninhydrin ${ }^{8)}$ reagents indicating a content of protein or peptide. The other spots 2 and 3 reacted with the ninhydrin and amidoblack$10 \mathrm{~B}$, but not with the methylene blue and PAS. These results show that the component 1 which has a negative net charge, is likely to be a sialoglycopeptide and the other components appear to be peptides. The component 1 was isolated by using paper electrophoresis under the conditions described in the section of experimental methods. Four paper strips were used for the first purification of the crude preparation. One hundred and four $\mathrm{mg}$ of the crude preparation was dissolved in $0.8 \mathrm{ml}$ of water and $0.2 \mathrm{ml}$ of the solution was applied to one paper strip as a bund. After electrophoresis, guide strip was stained with the methylene blue. The zone with mobility corresponding to the spot 1 was cut off, cut into pieces, and eluted twice with $200 \mathrm{ml}$ of water at $3-4^{\circ} \mathrm{C}$ for 20 hours. The eluates obtained from 4 paper strips were combined, concentrated to near dryness in a rotary evaporator at $30^{\circ} \mathrm{C}$, and dried over phosphorous pentoxide in a vacuum desiccator. The residue $(50.6 \mathrm{mg})$ was taken 
in $0.4 \mathrm{ml}$ of water and the solution was again subjected to preparative paper electrophoresis described above. Two paper strips were used for the second purification. Yield of the dry residue with faint yellow color was $27.2 \mathrm{mg}$. This residue will henceforth be refered to as the purified preparation. The results of paper electrophoresis of the purified preparation followed by staining with the 4 reagents of 4 ribbons, are shown in Fig. 2. As seen from the figures, the

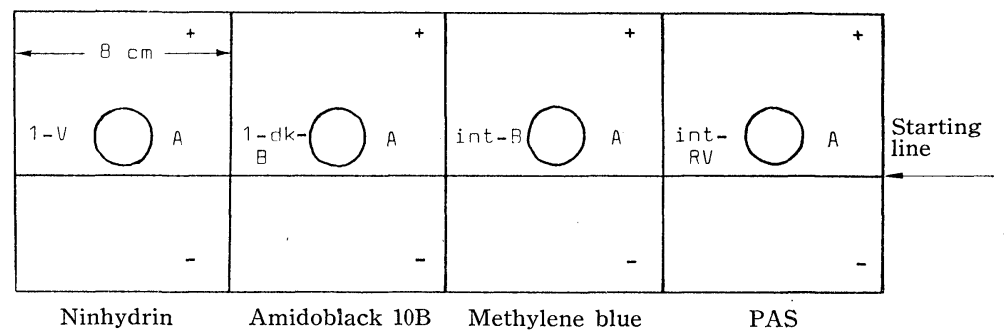

Fig. 2. Paper electropherogram of the purified preparation.

purified preparation gave only one spot which stained with both the methylene blue and PAS, but was slightly positive with the amidoblack-10 B and hardly reacted with the ninhydrin. These findings indicate that the purified preparation consists of one sialoglycopeptide which appears to be paper electrophoretic homogeneous. As seen from Figs. 1 and 2, the electrophoretic mobility of the sialoglycopeptide (the spot 1 in Fig. 1) in the crude preparation is greater than that of the sialoglycopeptide (the spot A in Fig. 2) of the purified preparation. Decrease of the electrophoretic mobility of the purified (isolated) sialoglycopeptide might be due to the release of some sialic acids by purification procedure from its peptide molecule. The electrophoretic mobility of I active sialoglycopeptide in the preceding paper, ${ }^{3)}$ was hardly affected by the purification under the same conditions. These findings show that the sialic acid linkage in the sialoglycopeptide molecule is more unstable than that in the I active sialoglycopeptide molecule.

Before and after incubation with crystalline chymotrypsin, the agglutinability of the $\mathrm{A}, \mathrm{B}, \mathrm{H}(\mathrm{O}), \mathrm{Le}^{\mathrm{a}}, \mathrm{M}, \mathrm{N}, \mathrm{S}, \mathrm{s}, \mathrm{I}, \mathrm{Jk}^{\mathrm{a}}, \mathrm{Jk}^{\mathrm{b}}, \mathrm{K}, \mathrm{k}, \mathrm{Fy}^{\mathrm{a}}$, $\mathrm{P}, \mathrm{Q}, \mathrm{C}\left(\mathrm{rh}^{\prime}\right), \mathrm{D}\left(\mathrm{Rh}_{0}\right), \mathrm{E}\left(\mathrm{rh}^{\prime \prime}\right), \mathrm{c}\left(\mathrm{hr}^{\prime}\right), \mathrm{e}\left(\mathrm{hr}^{\prime \prime}\right), \mathrm{Hg}, \mathrm{Wr}^{\mathrm{a}}, \mathrm{Sr}^{\mathrm{a}}, \mathrm{Wb}$, and $\mathrm{Kp}$ receptors on erythrocytes was qualitatively tested by their corresponding anti-sera. Erythrocytes tested were all negative by the $\mathrm{Le}^{\mathrm{a}}, \mathrm{K}, \mathrm{Hg}, \mathrm{Wr}^{\mathrm{a}}, \mathrm{Sr}^{\mathrm{a}}, \mathrm{Wb}$, and $\mathrm{Kp}$ tests. Some enhancement of agglutinability was observed for the $\mathrm{k}, \mathrm{Jk}^{\mathrm{b}}$, and $\mathrm{s}$ agglutinogens in some samples and A, B, H(O), M, N, S, I, Jk $\mathrm{Jk}^{\mathrm{b}}, \mathrm{K}, \mathrm{P}, \mathrm{Q}, \mathrm{C}, \mathrm{D}, \mathrm{E}, \mathrm{c}$, and $\mathrm{e}$ agglutinogens was not affected in all samples by treatment with crystalline chymotrypsin. The agglutinability of the $\mathrm{Fy}^{\mathrm{a}}$ receptor 
Table I. Absorption test of sialoglycopeptide with anti-Fy ${ }^{\mathrm{a}}$ serum

\begin{tabular}{c|c|c|c|c|c|c|c|c}
\hline \multirow{2}{*}{ Sample } & \multicolumn{8}{|c}{ Dilution } \\
\cline { 2 - 7 } & $\times 1$ & $\times 2$ & $\times 4$ & $\times 8$ & $\times 16$ & $\times 32$ & $\times 64$ & $\times 128$ \\
\hline Sialoglycopeptide & - & - & - & + & + & + & $H$ & H \\
\hline
\end{tabular}

was decreased after incubation with crystalline chymotrypsin or abolished in some samples. The purified sialoglycopeptide which was obtained from erythrocytes by digestion with crystalline chymotrypsin, specifically did absorb anti-Fy antibody as shown in Table I. These results seem to indicate that treatment of human erythrocytes with crystalline chymotrypsin in a low concentration of $0.0732 \mathrm{mg} / \mathrm{ml}$, results in release of a sialoglycopeptide possessing the $\mathrm{Fy}^{\mathrm{a}}$ blood-group activity and simultaneous decrease or destruction of the $\mathrm{Fy}^{\mathrm{a}}$ activity of their erythrocytes.

Summary. Treatment of human erythrocytes with crystalline chymotrypsin in a low concentration of $0.0732 \mathrm{mg} / \mathrm{ml}$, results in decrease of the $\mathrm{Fy}^{\mathrm{a}}$ activity of their erythrocytes and simultaneous liberation of a sialoglycopeptide with the $\mathrm{Fy}^{\mathrm{a}}$ activity.

Acknowledgement. We wish to thank Dr. Y. Matsuoka, of Eisai Research Laboratory, Tokyo, for a gift of crystalline chymotrypsin preparation.

\section{References}

1) Kabat, E. A.: Blood Group Substances. Their Chemistry and Immunochemistry. Academic Press Inc., New York, pp. 44-48 (1956).

2) Springer, G. F.: Bacteriol. Rev., 27, 191 (1963).

3) Ohkuma, S., and Ikemoto, S.: Proc. Japan Acad., 41, 482 (1965).

4) Morton, J. A.: Brit. J. Haematol., 8, 134 (1962).

5) Ohkuma, S., Shinohara, T., and Miyauchi, C.: Nature, 207, 527 (1965).

6) McGuckin, W. F., and McKenzie, B. F.: Clin. Chem., 4, 476 (1958).

7) Grassmann, W., and Hannig, K.: Z. Physiol. Chem., 290, 1 (1952).

8) Montgomery, R., and Wu, Y-C.: J. Biol. Chem., 238, 3547 (1963).

9) Ohkuma, S., Shinohara, T., and Miyauchi, C.: Proc. Japan Acad., 41, 332 (1965). 